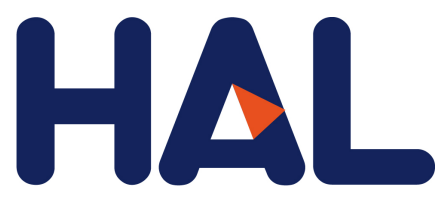

archives-ouvertes

\title{
Age-related changes in melatonin synthesis in rat extrapineal tissues
}

M Sanchez-Hidalgo, C Alarcon de la Lastra, Mp Carrascosa-Salmoral, Mc Naranjo, A Gomez-Corvera, B Caballero, Jm Guerrero

\section{- To cite this version:}

M Sanchez-Hidalgo, C Alarcon de la Lastra, Mp Carrascosa-Salmoral, Mc Naranjo, A Gomez-Corvera, et al.. Age-related changes in melatonin synthesis in rat extrapineal tissues. Experimental Gerontology, Elsevier, 2009, 44 (5), pp.328. 10.1016/j.exger.2009.02.002 . hal-00493098

\section{HAL Id: hal-00493098 \\ https://hal.archives-ouvertes.fr/hal-00493098}

Submitted on 18 Jun 2010

HAL is a multi-disciplinary open access archive for the deposit and dissemination of scientific research documents, whether they are published or not. The documents may come from teaching and research institutions in France or abroad, or from public or private research centers.
L'archive ouverte pluridisciplinaire HAL, est destinée au dépôt et à la diffusion de documents scientifiques de niveau recherche, publiés ou non, émanant des établissements d'enseignement et de recherche français ou étrangers, des laboratoires publics ou privés. 


\section{Accepted Manuscript}

Age-related changes in melatonin synthesis in rat extrapineal tissues

M Sanchez-Hidalgo, C Alarcon de la Lastra, MP Carrascosa-Salmoral, MC

Naranjo, A Gomez-Corvera, B Caballero, JM Guerrero

PII:

S0531-5565(09)00024-2

DOI: $\quad$ 10.1016/j.exger.2009.02.002

Reference: $\quad$ EXG 8579

To appear in: $\quad$ Experimental Gerontology

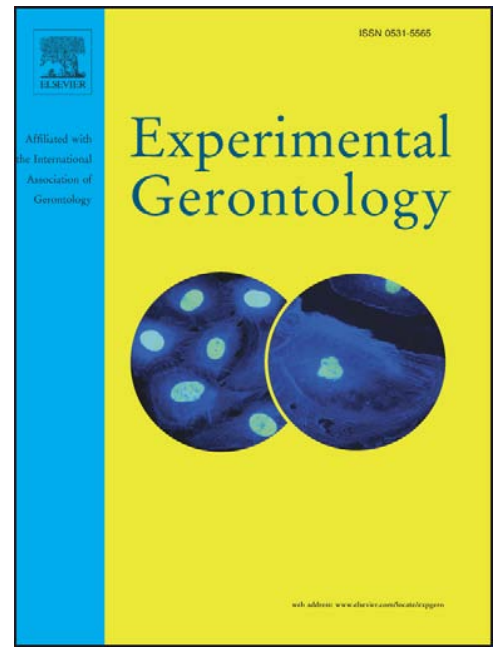

Received Date: $\quad 20$ October 2008

Revised Date: $\quad 19$ December 2008

Accepted Date: $\quad 11$ February 2009

Please cite this article as: Sanchez-Hidalgo, M., de la Lastra, C.A., Carrascosa-Salmoral, M., Naranjo, M., GomezCorvera, A., Caballero, B., Guerrero, J., Age-related changes in melatonin synthesis in rat extrapineal tissues, Experimental Gerontology (2009), doi: 10.1016/j.exger.2009.02.002

This is a PDF file of an unedited manuscript that has been accepted for publication. As a service to our customers we are providing this early version of the manuscript. The manuscript will undergo copyediting, typesetting, and review of the resulting proof before it is published in its final form. Please note that during the production process errors may be discovered which could affect the content, and all legal disclaimers that apply to the journal pertain. 


\section{Age-related changes in melatonin synthesis in rat extrapineal tissues}

M Sanchez-Hidalgo ${ }^{1,2}$, C Alarcon de la Lastra ${ }^{2}$, MP Carrascosa-Salmoral ${ }^{3}$, MC Naranjo $^{3}$, A Gomez-Corvera ${ }^{3}$, B Caballero ${ }^{4}$, JM Guerrero ${ }^{1,}{ }^{*}$.

${ }^{1}$, Department of Clinical Biochemistry, Biomedicine Institute of Seville (IBiS)/CSIC, University of Seville, Virgen del Rocío University Hospital, Seville, Spain.

${ }^{2}$, Department of Pharmacology, Faculty of Pharmacy, University of Seville, Seville, Spain,

${ }^{3}$, Department of Medical Biochemistry and Molecular Biology, University of Seville School of Medicine, Seville, Spain

${ }^{4}$, Departamento de Morfología y Biología Celular, Facultad de Medicina, Universidad de Oviedo, Oviedo, Spain.

* Corresponding author:

Dr. Juan M. Guerrero

Department of Clinical Biochemistry

Virgen del Rocío University Hospital

Manuel Siurot Street, s/n

41013, Seville

(Spain)

Phone: +34 955013243

e-mail: guerrero@us.es, hidalgosanz@us.es

Keywords: extrapineal melatonin, NAT, HIOMT, aging, neuroimmunomodulation 


\section{Abstract}

In the search of new therapeutic targets improving the quality of life of elderly, melatonin, "the chemical expression of darkness", seems to play a remarkable role in aging process possibly due to its antioxidant, immunoenhancer and antiaging properties. The present study was designed to elucidate effects of aging in melatonin extrapineal synthesis and investigate evident age-related alterations in the action mechanisms involved. The presence of the two key enzymes involved in melatonin synthesis, arylalkylamine- $\mathrm{N}$-acetyltransferase (AA-NAT) and hydroxyindole- $O$-methyltransferase (HIOMT) was analyzed in thymus, spleen, liver, kidney and heart of 3- and 12 monthold rats using real time PCR as well as its functionality by enzymatic activity assays. In addition, extrapineal melatonin content was measured by a competitive enzyme immunoassay (ELISA). The results of this study reveal that all rat tissues studied including thymus, and for the first time, spleen, liver, kidney and heart have the necessary machinery to synthesize melatonin. Moreover, we report an age-related decline in rat extrapineal melatonin synthesis with a consequent HIOMT functionality decrease in spleen, liver and heart during physiological aging. On the contrary, NAT enzymatic activity maintains unchanged without evident alterations with advancing age. Moreover, diminished melatonin concentrations were measured in these tissues cited above during aging except in the thymus, where, surprisingly, melatonin content, NAT/HIOMT expression, and enzymatic functionality assays revealed no significant alterations with age. As a conclusion, we report evident age-related changes in melatonin synthesis in some rat peripheral organs. We suggest that thymus may develop compensatory mechanisms to counteract the loss of immune activity and consequently, the loss of this potent antioxidant, during physiological aging. 


\section{Introduction}

Melatonin (N-actetyl-5-methoxy-tryptamine), an indolamine derived from the amino-acid tryptophan via synthesis of serotonin, was first isolated by Lerner et al in 1958 (Lerner et al., 1958). Melatonin, is produced by the pineal gland and secreted into the blood in a circadian manner. Its pineal production is triggered by darkness in the retina and the pineal gland, conferring the diurnal rhythm of melatonin, while in the peripheral system it is continuously produced in the gastrointestinal tract, especially in the stomach, and is triggered by innate immune response in the immune competent cells.

Melatonin participates in diverse physiological functions and has great functional versatility related to the regulation of circadian rhythms and seasonal behaviour (Reiter, 1991), sexual development (Roy and Belsham, 2001), retinal physiology (Lundmark et al., 2006), osteogenesis (Sanchez-Hidalgo et al., 2007), tumour inhibition, antioxidant, anti-aging (Anisimov et al., 2006) and immunoenhancer properties (Guerrero and Reiter, 2002). More recently, it has been also implicated in bone homeostasis, cardiovascular, neurological and gastrointestinal systems (PandiPerumal et al., 2006).

The enzymatic machinery for melatonin biosynthesis in pinealocytes was first identified by Axelrod in 1974 (Axelrod, 1974). Its biosynthesis is mediated by the sequential action of AA-NAT and HIOMT. The primary neurotransmitter, noradrenalinee, is released during the night from the postganglionic symphatic fibers of the superior cervical ganglion that terminate in the pinealocytes where it couples to $\beta$ adrenergic receptors. This leads to an activation of adenylate cyclase with a consequent rise in cAMP levels, promoting the novo protein synthesis and stimulating the ratelimiting enzyme in melatonin production, arylalkylamine-N-acetyltransferase (AA- 
NAT) (Klein et al., 1981). As a result, AA-NAT N-acetylates serotonin to Nacetylserotonin (NAS) and, as long as NAS is generated, is quickly $O$-methylated by hydroxyindole- $O$-methyltransferase (HIOMT) to finally produce melatonin (Axelrod y Weissbach, 1960). The dramatic rise in AA-NAT (10- to 100-fold) leads to melatonin synthesis which is released during periods of darkness in a circadian manner (Reiter, 1991). In contrast, the nocturnal increase in pineal HIOMT activity is weak but significant. HIOMT gene expression is high during daytime but displays an additional two fold increase at night. Once synthesized and released into blood at night, melatonin is transferred through biological membranes and is found throughout the organism in all body tissues within a very short period. This presence does not necessarily indicate an endogenous synthesis because the high lipophilic nature permits its transfer. To date, extrapineal melatonin synthesis has been demonstrated only in retina, harderian gland, brain, gut, ovary, testes, inner ear and immune system including bone marrow, lymphocytes, macrophages and, more recently, in thymus (Kvetnoy, 1999; Bubenik, 2002; Carrillo-Vico et al., 2004; Slominski et al., 2005). In general, while pineal melatonin seems to act as a typical hormone reaching target cells through the bloodstream, extrapineal melatonin may play a key role as an intra-, auto- and paracrine signal molecule in those tissues where it is synthesized (Carrillo-Vico et al., 2004).

The consequences of aging are also seen in melatonin production. The secretory dynamic of pineal melatonin attenuates gradually with age, resulting in a loss of nocturnal peak of melatonin with nearly undetectable plasma levels at 20-22 months of age in rodents (Reiter et al., 1980) and at 60-70 in humans (Touitou et al., 1985). Recent studies have suggested that age-related decline in melatonin concentration involves a loss of its antioxidant ability against damage produced by free radicals (Reiter et al., 2002). Thus, the loss of this potent antioxidant during aging may be consequential of 
the onset of age-related diseases. In fact, some studies in rodents have suggested that such diminished melatonin secretion may accelerate aging (Reiter, 1995) whereas melatonin administration has an immune reconstituting effect in aging (Tian et al., 2003). As mentioned above, pineal and serum melatonin levels decrease with advancing age, however little is known about the physiological roles of melatonin in extrapineal tissues during aging. The relevance of pineal and extrapineal melatonin in maintaining immune surveillance and defence response and the implication of reducing melatonin production by aging could support the idea that age-related decrease in extrapineal melatonin production should be very important for the developing of age-related diseases. Furthermore, the present study was designed to obtain a better understanding about melatonin produced in situ in rat peripheral organs, including the immune system, with age. That is why we studied the presence of the two key enzymes involved in melatonin synthesis, NAT and HIOMT, in thymus, spleen, liver, kidney and heart of rats of 3- and 12 month-old using real time PCR as well as its functionality by enzymatic activity assays. In addition, the extrapineal melatonin content was measured by a competitive enzyme immunoassay (ELISA).

\section{Material and methods}

\subsection{Animals and tissue preparations}

Experiments were performed on male Wistar rats (3- and 12 month-old) supplied by Production and Experimentation Animal Services from the University of Granada, Spain. Animals were placed singly in cages at a controlled room temperature $24-25^{\circ} \mathrm{C}$, humidity 70-75\%, under controlled photoperiods of $12 \mathrm{~h}$ light: $12 \mathrm{~h}$ darkness (lights were turned off daily from 20:00 to $08: 00 \mathrm{~h}$ ) and were maintained with a normal laboratory diet (Panlab, Barcelona, Spain) and water ad libitum. The experiments followed a protocol approved by the local animal Ethics Committee and the Local Government and all 
experiments were in accordance to the recommendations of the European Union regarding animal experimentation (Directive of the European Counsel 86/609/EC).

When required, 3- and 12 month-old rats were sacrificed by decapitation between 12:00 and 15:00 $\mathrm{h}$, and the organs were carefully removed under sterile conditions, briefly rinsed in normal saline solution, frozen on solid $\mathrm{CO}_{2}$ and stored at $-80^{\circ} \mathrm{C}$ until their use for RNA extraction, enzyme activities and melatonin determinations.

\subsection{Total RNA extraction and reverse transcription}

Total RNA was extracted from samples by a modification of Chomczynski and Sacchi's method using TriPure Isolation Reagent (Roche, Mannheim, Germany) as a denaturing solution and appropriate chloroform volume. After cell lysis and RNA extraction, RNA was precipitated with isopropanol, and the pellet was washed in $75 \%$ ethanol. The RNA samples were recovered by centrifugation at $14000 \mathrm{~g}$ for $5 \mathrm{~min}$ and then dried. Each RNA pellet was dissolved in 50 or $100 \mu \mathrm{L}$ RNase-free water and the quantified spectrophotometrically at $260 \mathrm{~nm}$. In an attempt to discard DNA contamination before cDNA synthesis, the RNA samples underwent a purification process. A determined volume of reaction buffer 10x $(100 \mathrm{mM}$ Tris $\mathrm{pH} 7.5,25 \mathrm{mM}$ $\mathrm{MgCl}_{2}, 5 \mathrm{mM} \mathrm{CaCl}{ }_{2}$ ) and DNAsa I (Roche, 2U/ $10 \mu \mathrm{g} \mathrm{ARN)}$ were added to RNA extracted volume and incubated at $37^{\circ} \mathrm{C}$ for $30 \mathrm{~min}$. The enzymatic inactivation was at $65^{\circ} \mathrm{C}$ for $10 \mathrm{~min}$. The samples were centifuged at $2500 \mathrm{~g}$ at $4^{\circ} \mathrm{C} 5 \mathrm{~min}$ after phenolchloroform addition and RNA was precipitated with absolute ethanol, dissolved in 50 $\mu \mathrm{L}$ RNase-free water and the quantity and quality of RNA was assessed spectrophotometrically at $260 \mathrm{~nm}$ and $260 / 280 \mathrm{~nm}$, respectively.

Single-strand cDNA was then synthesized using the following method: $5 \mu \mathrm{g}$ of RNA was denatured in $19 \mu \mathrm{L}$ RNase-free water at $85^{\circ} \mathrm{C}$ for $10 \mathrm{~min}$, and then rapidly 
chilled on ice. Then, $21 \mu \mathrm{L}$ of a mixture formed by $1 \mathrm{X}$ reverse transcription (RT) buffer, $20 \mathrm{mM}$ dithiothreitol (DTT), 2'-deoxyribonucleoside-5'-triphosphates $(0.5 \mathrm{mM}$ of each), $40 \mathrm{U}$ recombinant $\mathrm{RNasin}$ ribonuclease inhibitor, $0.5 \mu \mathrm{g}$ oligo $(\mathrm{dT})_{15}$ primer and 200 U Moloney murine leukemia virus reverse transcriptase (M-MLV RT) were added to give a final volume of $40 \mu \mathrm{L}$ and incubated for 60 min at $42^{\circ} \mathrm{C}$ (all reagents were purchased from Promega, Madison, WI, USA). The RT reaction was terminated by placing it on ice after deactivation at $95^{\circ} \mathrm{C}$ for $5 \mathrm{~min}$.

\subsection{Real Time RT-PCR}

Real time quantitative PCR was performed by the MiniOpticon cycler system (BioRad ${ }^{\circledR}$ ) using the $2 \mathrm{X}$ SensiMix DNA Kit (Quantace). The cDNA was amplified in a reaction containing $5 \mu \mathrm{L}$ of RT product as template DNA (200 ng), 1 X Sensi Mix (reaction buffer, dNTPs, Taq DNA polymerase, $3 \mathrm{mM} \mathrm{MgCl}_{2}$ ), 1 X SYBR Green and $0.2 \mu \mathrm{M}$ sense and antisense primers of the gene under study or $0.1 \mu \mathrm{M}$ for the housekeeping gene (hprt), in a final volume of $25 \mu \mathrm{L}$. The sequences of primers are shown in Table 1.

The PCR reaction started by a 10 min activation of hot-start DNA polymerase at $95^{\circ} \mathrm{C}$ followed by 45 cycles of target cDNA amplification. The template was initially denatured at $95^{\circ} \mathrm{C} 10 \mathrm{~s}$ followed by 45 -cycle program with $20 \mathrm{~s}$ annealing at $57^{\circ} \mathrm{C}$ (AA-NAT) or $45 \mathrm{~s}$ annealing at $58-60^{\circ} \mathrm{C}(\mathrm{HIOMT})$ and $20 \mathrm{~s}$ elongation at $72^{\circ} \mathrm{C}$ and acquisition of SYBR Green fluorescence. In addition, the ubiquitously expressed hprt mRNA was used to monitor the quality of RNAs and the efficiency of the RT and PCR processes. During PCR the intercalate agent is separated resulting in increased fluorescence. The MiniOpticon instrument reads each well every few seconds and measures the increase in fluorescence which is a direct consequence of the target amplification during PCR. The results are reported as threshold cycle $(\mathrm{Ct})$ values, the 
cycle at which fluorescence readings exceed the mean baseline readings. The mathematical model of $2^{-\triangle \Delta C T}$ (Livak) was used for relative quantification of AANAT and HIOMT to hprt using the equation: $\Delta \Delta \mathrm{C}_{\mathrm{T}}=(\mathrm{Ct}$, target $-\mathrm{Ct}$, hprt $)$ Time $\mathrm{x}-$ $(\mathrm{Ct}$, target $-\mathrm{Ct}$, hprt)Time 0 ; where time $\mathrm{x}$ is any time point and time 0 represents the $1 \mathrm{X}$ expression of the target gene normalized to hprt. The mean, and SD were then determined from the triplicate samples at each time point. The value of the mean fold change at zero time should be very close to one $\left(2^{0}=1\right)$.

\subsection{NAT activity assay}

NAT activity was determined by the method of Champney et al. (1984). Each tissue sample (thymus, spleen, liver, kidney and heart) was homogenated at $4^{\circ} \mathrm{C}$ in an appropriate volume of $0.05 \mathrm{M}$ phosphate-buffered saline buffer (PBS), $\mathrm{pH}$ 6.8, using a cell sonicator (Sonics and Materials Inc., Danbury CT, USA). Ten microliters of this homogenate were mixed with $10 \mu \mathrm{L}$ PBS containing $40 \mathrm{n} \mathrm{Ci}\left[1-{ }^{14} \mathrm{C}\right]$ acetylcoenzyme A and $5.6 \mathrm{mM}$ tryptamine. The reaction was carried out for $20 \mathrm{~min}$ at $37^{\circ} \mathrm{C}$, and was stopped by the addition of $100 \mu \mathrm{L} 0.2 \mathrm{M}$ sodium borate buffer, $\mathrm{pH} 10$, and $1 \mathrm{ml}$ chloroform at $4^{\circ} \mathrm{C}$. The $\mathrm{N}$-acetyltrypamine produced was extracted with chloroform and its radioactivity was measured by liquid scintillation spectrometry with a beta counter. NAT activity was expressed as pmol $\mathrm{N}$-acetyltryptamine produced per mg protein per $\mathrm{h}$. Protein content was measured following the Bradford protocol (Bradford, 1976).

\subsection{HIOMT activity assay}

HIOMT activity was determined by the method of Champney et al (1984) by measuring the amount of melatonin formed from N-acetylserotonin and S-adenosyl-Lmethionine. Each sample was homogenated in $0.05 \mathrm{M}$ PBS, pH 6.8. Forty microliters of this homogenate were mixed with $20 \mu \mathrm{L} 0.05$ M PBS, pH 7.9, containing 20n Ci S[methyl- ${ }^{14} \mathrm{C}$ ] adenosyl-L-methionine and $3 \mathrm{mM} \mathrm{N}$-acetylserotonin. The reaction was 
incubated for $30 \mathrm{~min}$ at $37^{\circ} \mathrm{C}$ and stopped by the addition of $100 \mu \mathrm{L} 0.2 \mathrm{M}$ sodium borate buffer $\mathrm{pH} 10$ and $1 \mathrm{~mL}$ chloroform at $4^{\circ} \mathrm{C}$. Synthesized melatonin was measured following extraction in $1 \mathrm{~mL}$ chloroform and the radioactivity by liquid scintillation spectrometry counted with a beta counter. HIOMT activity was expressed as pmol melatonin per mg protein per h. Protein content was measured following the Bradford protocol (Bradford, 1976).

\subsection{Melatonin determination by ELISA}

Melatonin levels were determined by a competitive enzyme immunoassay kit (Immuno Biological Laboratories, Hamburg, Germany). Tissues were weighed (60-100 $\mathrm{mg}$ ) and homogenated in an appropriate volume of PBS in a sonicator (Sonics and Materials Inc., Danbury CT, USA) and centrifuged at $3000 \mathrm{~g}$ for $10 \mathrm{~min}$. Tissue homogenate supernatants were used for melatonin determinations. An aliquot was used to measure protein concentration so as to refer the melatonin measures to mg protein following the Bradford colorimetric method.

Melatonin was extracted from $500 \mu \mathrm{L}$ of samples, standards, and controls (90$100 \%$ yield recovery) using C18 reversed-phase columns (IBL-Hamburg, Germany) and methanol elution. The dried extracts (after evaporating methanol) were reconstituted with water. Then, each sample was added to the corresponding well coated with captured antibody goat anti-rabbit Ig of a 96-well microtiter plate. Each microtiter plate was filled either with $50 \mu \mathrm{L}$ blank reagent, extracted calibrators, extracted samples or extracted standard solutions (containing $0,3,10,30,100$ or $300 \mathrm{pg} / \mathrm{mL}$ melatonin). Then, $50 \mu \mathrm{L}$ melatonin biotin and $50 \mu \mathrm{L}$ rabbit-antiserum were added into each well, shaken carefully, sealed with adhesive foil and incubated overnight $(14-20 \mathrm{~h})$ at $2-8^{\circ} \mathrm{C}$. After washing three times with $250 \mu \mathrm{L}$ diluted assay buffer, $150 \mu \mathrm{L}$ anti-biotin conjugate to alkaline phosphatase was added into each well and incubated for $2 \mathrm{~h}$ at 
room temperature. The reaction was developed using $p$-nitrophenyl phosphate (PNPP) substrate solution and optical densities were determined at $450 \mathrm{~nm}$ in an automatic microplate reader. The melatonin concentration was inversely proportional to the optical density measured. Melatonin standards were used to construct a calibration curve against which the unknown samples were calculated. The sensitivity of the melatonin assay was $3.0 \mathrm{pg} / \mathrm{mL}$. Both the intra- and inter-assay coefficients of variation (CV) were less than $10 \%$.

\subsection{Statistical data analysis}

The presented data are expressed as means \pm standard error of the mean (SEM). The data were evaluated with Graph Pad Prism ${ }^{\circledR}$ (Version 2.01) software. The statistical significance of any difference in each parameter among the groups was evaluated by Student's $t$-test or the Mann-Whitney U-test (for non-parametric values). $P$ values of $<0.05$ were considered statistically significant.

\section{Results}

RNA from all samples was isolated and RT and PCR amplification assays were performed. cDNA obtained from the pineal gland was used as a positive control. Quantitative real-time PCR assays were established for HPRT (housekeeping gene), AA-NAT (rate-limiting enzyme in melatonin synthesis) and HIOMT (the final enzyme of the biosynthetic pathway) (Figs. 1 and 2). For each PCR run, a negative control was systematically added, in which RNase-free water replaced cDNA. In addition, a single peak was observed for each of the products by melting curve analysis, performed routinely in all samples after amplification. Product Tm values were: HPRT $81^{\circ} \mathrm{C}$, AANAT $86.6^{\circ} \mathrm{C}$, HIOMT $84.5^{\circ} \mathrm{C}$. No product was detected in the absence of RT in any assay for any of the products, thus indicating that there was no genomic contamination. 
Data for 12 month-old samples were normalized by those obtained for 3 month-old samples.

As shown in figures 1 and 2, significant levels of AA-NAT and HIOMT transcripts were described in all tissues studied. According to AA-NAT expression, the relative quantification assay revealed significant differences in AA-NAT mRNA expression of 12 month-old rats when compared with values obtained in control group (Fig.1). Particularly, a significant decrease in AA-NAT mRNA expression was observed in spleen and liver from middle-aged rats $(P<0.01$ and $P<0.001$, respectively). On the contrary, AA-NAT mRNA expression levels were significantly higher in kidney $(P<0.01)$ and heart $(P<0.05)$ during aging while no significant differences were observed between values of thymus from 3- and 12 month-old rats. Likewise, we studied HIOMT mRNA levels in the tissues cited above; values of relative expression of HIOMT mRNA in thymus, spleen, kidney, liver and heart from 3- and 12 month-old rats are shown in figure 2. Once again, we observed age-related significant differences depending on the tissue studied. For instance, we observed a significant increase in HIOMT mRNA levels in spleen and heart of 12 month-old rats $(P<0.05)$ whereas an age-related reduction $(P<0.001)$ was observed in liver when compared with young control group. No significant differences related to HIOMT expression were detected in thymus and kidney as age increased.

To obtain a deeper insight of mechanisms involved in melatonin regulation of the immune system and other peripheral organs during aging, we analyzed the functionality of the enzymatic machinery involved in melatonin synthesis by measuring the enzymatic activity of NAT and HIOMT. Pineal homogenate was used as a positive control of the assay. Results obtained in enzymatic activity assays confirmed evident age-related changes in NAT and HIOMT activity levels (Figs. 3 and 4). As regards to 
NAT activity (Fig. 3), results showed that NAT enzyme is active in all tissues from 3and 12 month-old rats. Results obtained in liver and kidney demonstrate that middleaged rats increased the NAT activity levels, showing a twofold increase when compared with control group animals, $P<0.05$ and $P<0.001$, respectively. However, the NAT activity levels from the rest of tissues studied remained unchanged with advancing age. In relation to HIOMT activity, we observed a significant age-related reduction in spleen, liver and heart of 12 month-old rats, $P<0.05$ (Fig. 4). However, HIOMT activity values remained constant in middle-aged rat thymus and kidney showing no age-related modifications.

Since melatonin levels produced by pineal gland have been found to decrease with age, we wished to know what would happen to melatonin produced in situ in peripheral organs including immune system. Therefore, melatonin content in extrapineal tissues of rats 12 month-old was measured by ELISA and compared with melatonin content obtained from the young control group (Fig. 5). The results, expressed as pg melatonin / $\mu \mathrm{g}$ protein, showed unexpectedly higher levels of melatonin in kidney and thymus of middle-aged rats when compared with those obtained in 3 month-old rats, $P<$ 0.05 and $P<0.001$, respectively. However, melatonin content produced by the spleen, liver and heart decreased significantly with age, $P<0.05$.

\section{Discussion}

Aging is a physiological process that involves a number of biochemical reactions, with molecular changes that are manifested in the organism. Particularly, the impairment of the immune efficiency that occurs in aging (Miller, 1991) known as immunosenescence is associated with increased incidence of cancer, infectious and degenerative diseases. Innate, cellular and humoral immunity all exhibit increased 
deterioration with age. Moreover, it has reported that aging also implies a decline in the production of several hormones including melatonin, and this drop seems to play a remarkable role in contributing to the immunosenescence due to its immunoenhancer and anti-aging properties (Srinivasan et al., 2005).

Since melatonin was first isolated five decades ago until it was identified in extrapineal tissues, twenty years later, it was considered as a hormone exclusive to the pineal gland. To date, its presence has been described in a large number of extrapineal sites including immune system, gut, reproductive organs, brain and skin (Hardeland, 2008). Although the presence of melatonin in extrapineal sites is becoming more and more evident, the potential physiological actions of this endogenous melatonin have not yet been studied. On the other hand, it is well-known that reduced melatonin concentrations have been described in the pineal gland, serum and also in urine during aging (Reiter et al., 1981; Miguez et al., 1998; Pang et al., 1983; Bondarenko, 1992). However, what happens to melatonin produced in situ in peripheral organs with advancing age as well as the melatonin physiological functions implicated in these tissues remains undefined. Therefore, the present study was designed to elucidate effects of aging in melatonin extrapineal synthesis and investigate the possible agerelated alterations in the action mechanisms implicated. The results of this study demonstrate that all rat tissues studied including thymus, and for the first time, spleen, liver, kidney and heart have the necessary machinery to synthesize melatonin, which would indicate that at least a part of observed melatonin levels come from endogenous synthesis. We also detected expression and activities of the two key enzymes involved in melatonin synthesis as well as significant changes in melatonin levels with advancing age. Our data reveal, not only the presence of NAT and HIOMT mRNAs in rat thymus, spleen, liver, kidney and heart, but also age-related expression differences of both key 
melatonin biosynthetic enzymes using the relative quantification method. Regarding the immune system, enzymatic machinery expression involved in melatonin synthesis has been demonstrated in lymphoid organs including thymus (Naranjo et al., 2007), bone marrow (Tan et al., 1999; Conti et al., 2000), peripheral blood mononuclear leucocytes (Pozo et al., 2004) and in human cultured lymphocytes (Carrillo-Vico et al., 2004). Our results confirmed that all extrapineal tissues studied express both necessary key enzymes for melatonin synthesis, as opposed to Stefulj et al., who showed that neither rat immune system (thymus and spleen) nor other peripheral organs (kidney, liver and heart) contain reliable amounts NAT and/or HIOMT (Stefulj et al., 2001). This discrepancy might be due to a different amplification method used (PCR conventional vs. real time PCR).

AA-NAT enzyme seems to be present in all peripheral tissues studied from 3and 12 month-old rats, except in kidney and spleen of 12 month-old rats where we clearly observed a trend to decrease with age. However, NAT enzymatic assay revealed that NAT enzyme continues to be functional in all cited tissues in spite of aging process. Likewise, HIOMT expression study revealed the presence of this enzyme in all of them as well as a significant increase in spleen and heart during aging. On the contrary, HIOMT expression levels diminished significantly in liver of 12 month-old rats. Unexpectedly, the diurnal rhythm of melatonin content did not follow the same pattern as the enzymes. This discrepancy in expression/activity agrees with the published literature (Bernard et al., 1993; Sakamoto and Ishida, 1998).

Melatonin content measurement revealed a significant decrease in spleen, liver and heart from middle-aged rats whereas melatonin levels were significantly higher in thymus and kidney. Particularly, the increase observed in melatonin content in the kidney is according to the increase in NAT activity, suggesting that there is a direct 
correlation between both parameters. Nevertheless, these results agree with those obtained in HIOMT enzymatic activity assay. When melatonin levels and HIOMT functionality decrease significantly in spleen, heart and liver during rat physiological aging process, NAT enzymatic activity remains unchanged (spleen and heart) or increases (liver) possibly due to a feedback mechanism by which the organism attempts to compensate the drop in this potent antioxidant. Particularly, the age-related decrease in melatonin levels observed in these tissues did not result in a corresponding reduction in NAT activity. These data suggest that HIOMT enzymatic activity determines the level of melatonin synthesis in the above mentioned tissues during aging. In accordance with Simonneaux and Ribelayga, any modification in HIOMT activity could modulate, consequently, the melatonin production phase (Simonneaux and Ribelayga, 2003). In this sense, HIOMT enzyme may be the first key enzyme involved in melatonin synthesis that suffers the consequences of aging. In agreement with previous results reported by Liu and Borjigin we suggest that HIOMT should be considered the ratelimiting enzyme in the melatonin synthesis during aging (Liu and Borjigin, 2005).

With advancing age, the amount of free radicals increases considerably in cells, leading them to cell death. In this sense, although the melatonin physiological role in extrapineal tissues is not fully known, we should take into account its antioxidant and anti-aging properties (Reiter et al., 2002). It has been demonstrated that melatonin can prevent age-related diseases (Karasek, 2004) and some studies in rodents suggest that such diminished melatonin secretion may accelerate aging (Reiter, 1995). Likewise, an accumulation of oxidative products in many organs has been described after pinealectomy in aging rats (Reiter et al., 1999).Consequently, if melatonin levels contribute to the antioxidant capacity, such ability would be reduced in advanced age and could have severe effects. As a result, an age-related decline in melatonin levels 
may contribute to an increase in the oxidative damage and the onset of age-related degenerative diseases due to an accumulation of free radicals. Endogenous melatonin may act as free radical scavenger protecting the cells against oxidative damage associated to the aging. Surprisingly, of the rat extrapineal tissues studied, we have to highlight the results obtained in thymus for thymic mRNA expression and enzyme activity studies as well as the melatonin content measured since these parameters remained unchanged during aging. This could be explained by taking into account the bidirectional communication circuit between pineal melatonin and the immune system (Skwarlo-Sonta et al., 2003; Markus et al., 2007). The pineal gland, via the rhythmic synthesis and release of melatonin, influences the development, differentiation and function of the immune system. This connection is supported by studies which have demonstrated a correlation between melatonin production and circadian and seasonal variations in the immune system, effects of surgical or functional pinealectomy on the immune system, as well as the presence of melatonin receptors in the immune system (Guerrero and Reiter, 2002). Our results suggest that a feedback circuit may exist between the thymus and the pineal which balances the immunologic function in the body. In this sense, when the pineal gland starts to degenerate, the thymus may develop compensatory mechanisms such as maintaining NAT enzymatic functionality to counteract the loss of immune activity.

A bloodstream melatonin retention cannot completely be ruled out. Thus, we suggest that, despite action mechanisms involved in melatonin synthesis fail with advancing age, melatonin may be retained by the thymus from the bloodstream or intracellular space for transport to other organs where it exerts its effects or synthesized by the thymus, or both, counteracting the age-associated alterations. Our results agree with the high melatonin levels described in bone marrow (Tan et al., 1999), rat thymus 
(Naranjo et al., 2007) and those reported by Jimenez-Jorge et al. (2005). Pinealectomized rats have clearly increased thymic melatonin content evidencing an endogenous synthesis and suggesting that either pineal melatonin could be inhibiting thymic melatonin synthesis and when rat pinealecthesized melatonin is absent, the thymus could show a compensatory rise in melatonin production (Jimenez-Jorge et al., 2005).

Taken together, our study reveals that all rat extapineal tissues studied including thymus, and for the first time, spleen, liver, kidney and heart have the necessary machinery to synthesize melatonin. Moreover, we report an age-related decline in rat extrapineal melatonin synthesis in some organs. When melatonin levels and HIOMT functionality decrease in some organs during rat physiological aging process, the thymus would try to counteract the loss of this potent antioxidant by maintaining NAT enzymatic activity unchanged via pineal gland axis. Nonetheless, further studies are required in order to obtain a better understanding about the role of melatonin in these extrapineal tissues under physiological conditions as well as the relevance of extrapineal melatonin synthesis, including the regulation on the immune system, with advancing age.

\section{Acknowledgements}

This work was supported by grants of the Andalucía (P06-CTS-1604) and Spanish (PI 060091; RD06/00130001) governments. MSH gratefully acknowledges support from a Postgraduate National Program of FPU fellowship and financial sponsorship from the Spanish MEC. 


\section{References}

Anisimov, V.N., Popovich, I.G., Zabezhinski, M.A., Anisimov, S.V., Vesnushkin, G.M.,Vinogradova, I.A., 2006. Melatonin as antioxidant, geroprotector and anticarcinogen. Biochim Biophys Acta. 1757, 573-89.

Axelrod, J. 1974. The pineal gland: a neurochemical transducer. Science. 184, 1341-8.

Axelrod, J., Weissbach, H., 1960. Enzymatic O-methylation of N-acetylserotonin to melatonin. Science. 131, 1312.

Bernard, M., Guerlotte, J., Cogne, M., Greve, P., Collin, J.P.,Voisin, P., 1993. Transcriptional regulation of hydroxyindole O-methyltransferase in the chicken pineal gland: day/night changes and long-term effects of light and darkness. Biochem J. 290, 661-4.

Bondarenko, L.O., 1992. The comparative evaluation of the effect of the season on the formation of a nighttime melatonin peak in young sexually mature and old rats. Fiziol Zh. 38, 111-4.

Bradford, M.M., 1976. A rapid and sensitive method for the quantitation of microgram quantities of protein utilizing the principle of protein-dye binding. Anal Biochem. 72, 248-54.

Bubenik, G.A., 2002. Gastrointestinal melatonin: localization, function, and clinical relevance. Dig Dis Sci. 47, 2336-48. 
Carrillo-Vico, A., Calvo, J.R., Abreu, P., Lardone, P.J., Garcia-Maurino, S., Reiter, R.J., Guerrero, J.M., 2004. Evidence of melatonin synthesis by human lymphocytes and its physiological significance: possible role as intracrine, autocrine, and/or paracrine substance. Faseb J.18, 537-9.

Conti, A., Conconi, S., Hertens, E., Skwarlo-Sonta, K., Markowska, M., Maestroni, J.M., 2000. Evidence for melatonin synthesis in mouse and human bone marrow cells. J Pineal Res. 28, 193-202.

Champney, T.H., Holtorf, A.P., Steger, R.W., Reiter, R.J., 1984. Concurrent determination of enzymatic activities and substrate concentrations in the melatonin synthetic pathway within the same rat pineal gland. J Neurosci Res. 11, 59-66.

Guerrero, J.M., Reiter, R.J., 2002. Melatonin-immune system relationships. Curr Top Med Chem. 2, 167-79.

Hardeland, R., 2008. Melatonin, hormone of darkness and more - occurrence, control mechanisms, actions and bioactive metabolites. Cell Mol Life Sci.

Jimenez-Jorge, S., Jimenez-Caliani, A.J., Guerrero, J.M., Naranjo, M.C., Lardone, P.J., Carrillo-Vico, A., Osuna, C., Molinero, P., 2005. Melatonin synthesis and melatonin-membrane receptor (MT1) expression during rat thymus development: role of the pineal gland. J Pineal Res. 39, 77-83.

Karasek, M., 2004. Melatonin, human aging, and age-related diseases. Exp Gerontol. 39, 1723-9.

Klein, D.C., Namboodiri, M.A., Auerbach, D.A., 1981. The melatonin rhythm generating system: developmental aspects. Life Sci. 28, 1975-86.

Kvetnoy, I.M., 1999. Extrapineal melatonin: location and role within diffuse neuroendocrine system. Histochem J. 31, 1-12. 
Lerner, A.B., Case, J.D., Takahashi, Y., 1960. Isolation of melatonin and 5methoxyindole-3-acetic acid from bovine pineal glands. J Biol Chem. 235, 1992-7.

Liu, T., Borjigin, J., 2005. N-acetyltransferase is not the rate-limiting enzyme of melatonin synthesis at night. J Pineal Res. 39, 91-6.

Lundmark, P.O., Pandi-Perumal, S.R., Srinivasan, V., Cardinali, D.P., 2006. Role of melatonin in the eye and ocular dysfunctions. Vis Neurosci. 23, 853-62.

Markus, R.P., Ferreira, Z.S., Fernandes, P.A., Cecon, E., 2007. The immune-pineal axis: a shuttle between endocrine and paracrine melatonin sources. Neuroimmunomodulation. 14, 126-33.

Miguez, J.M., Recio, J., Sanchez-Barcelo, E., Aldegunde, M., 1998. Changes with age in daytime and nighttime contents of melatonin, indoleamines, and catecholamines in the pineal gland: a comparative study in rat and Syrian hamster. J Pineal Res. 25, 106-15.

Miller, R.A., 1991. Aging and immune function. Int Rev Cytol. 124, 187-215.

Naranjo, M.C., Guerrero, J.M., Rubio, A., Lardone, P.J., Carrillo-Vico, A., CarrascosaSalmoral, M.P., Jimenez-Jorge, S., Arellano, M.V., Leal-Noval, S.R., Leal, M., Lissen, E., Molinero, P., 2007. Melatonin biosynthesis in the thymus of humans and rats. Cell Mol Life Sci. 64, 781-90.

Pandi-Perumal, S.R., Srinivasan, V., Maestroni, G.J., Cardinali, D.P., Poeggeler, B., Hardeland, R., 2006. Melatonin: Nature's most versatile biological signal? Febs J.273, 2813-38.

Pang, S.F., Tang, P.L., 1983.Decreased serum and pineal concentrations of melatonin and $\mathrm{N}$-acetylserotonin in aged male hamsters. Horm Res. 17, 228-34. 
Reiter, R.J., 1991. Melatonin: the chemical expression of darkness. Mol Cell Endocrinol. 79,C153-8.

Reiter, RJ., 1995. Oxidative processes and antioxidative defense mechanisms in the aging brain. Faseb J. 9, 526-33.

Reiter, R.J., Cabrera, J., Sainz, R.M., Mayo, J.C., Manchester, L.C., Tan, D.X., 1999 Melatonin as a pharmacological agent against neuronal loss in experimental models of Huntington's disease, Alzheimer's disease and parkinsonism. Ann N Y Acad Sci. 890, 471-85.

Reiter, R.J., Richardson, B.A., Johnson, L.Y., Ferguson, B.N., Dinh, D.T. 1980. Pineal melatonin rhythm: reduction in aging Syrian hamsters. Science. 210, 1372-3.

Reiter, R.J., Tan, D., Kim, S.J., Manchester, L.C., Qi, W., Garcia, J.J., Cabrera, J.C., ElSokkary, G., Rouvier-Garay, V., 1999b. Augmentation of indices of oxidative damage in life-long melatonin-deficient rats. Mech Ageing Dev. 110, 157-73.

Reiter, R.J., Tan, D.X., Manchester, L.C., El-Sawi, M.R., 2002. Melatonin reduces oxidant damage and promotes mitochondrial respiration: implications for aging. Ann N Y Acad Sci. 959, 238-50.

Roy, D., Belsham, D.D., 2002. Melatonin receptor activation regulates GnRH gene expression and secretion in GT1-7 GnRH neurons. Signal transduction mechanisms. J Biol Chem. 277, 251-8.

Sakamoto, K., Ishida, N., 1998. Circadian expression of serotonin N-acetyltransferase mRNA in the rat retina. Neurosci Lett. 245, 113-6.

Sanchez-Hidalgo, M., Lu, Z., Tan, D.X., Maldonado, M.D., Reiter, R.J., Gregerman, R.I., 2007. Melatonin inhibits fatty acid-induced triglyceride accumulation in ROS17/2.8 cells: implications for osteoblast differentiation and osteoporosis. Am J Physiol Regul Integr Comp Physiol. 292, R2208-15. 
Simonneaux, V., Ribelayga, C., 2003. Generation of the melatonin endocrine message in mammals: a review of the complex regulation of melatonin synthesis by norepinephrine, peptides, and other pineal transmitters. Pharmacol Rev. 55, 32595.

Skwarlo-Sonta, K., Majewski, P., Markowska, M., Oblap, R., Olszanska, B., 2003. Bidirectional communication between the pineal gland and the immune system. Can J Physiol Pharmacol. 81, 342-9.

Slominski, A., Fischer, T.W., Zmijewski, M.A., Wortsman, J., Semak, I., Zbytek, B., Slominski, R.M., Tobin, D.J., 2005. On the role of melatonin in skin physiology and pathology. Endocrine. 27, 137-48.

Srinivasan, V., Maestroni, G.J., Cardinali, D.P., Esquifino, A.I., Perumal, S.R., Miller, S.C., 2005. Melatonin, immune function and aging. Immun Ageing. 2, 17.

Stefulj, J., Hortner, M., Ghosh, M., Schauenstein, K., Rinner, I., Wolfler, A., Semmler, J., Liebmann, P.M., 2001. Gene expression of the key enzymes of melatonin synthesis in extrapineal tissues of the rat. J Pineal Res. 30, 243-7.

Tan, D.X., Manchester, L.C., Reiter, R.J., Qi, W.B., Zhang, M., Weintraub, S.T., Cabrera, J., Sainz, R.M., Mayo, J.C., 1999. Identification of highly elevated levels of melatonin in bone marrow: its origin and significance. Biochim Biophys Acta. 1472, 206-14.

Tian, Y.M., Zhang, G.Y., Dai, Y.R., 2003. Melatonin rejuvenates degenerated thymus and redresses peripheral immune functions in aged mice. Immunol Lett. 88, 1014. 
Touitou, Y., Fevre-Montange, M., Proust, J., Klinger, E., Nakache, J.P., 1985. Age- and sex-associated modification of plasma melatonin concentrations in man. Relationship to pathology, malignant or not, and autopsy findings. Acta Endocrinol (Copenh). 108(1), 135-44. 
Figure 1. Real time PCR analysis of AA-NAT mRNA expression in extrapineal tissues spleen, kidney, liver and heart from 3- and 12 month-old rats are shown as mean \pm SEM of three experiments performed in triplicate. Data for 12 month-old samples were normalized by those obtained for 3 month-old samples. Hprt gene was used as a housekeeping gene. Significant statistically changes in AA-NAT mRNA expression were observed during aging. $(*), P<0.05,(* *), P<0.01$ and $(* * *), P<0.001$.

Figure 2. Real time PCR analysis of HIOMT mRNA expression in extra pineal tissues of 3- and 12 month-old rats. Values of HIOMT mRNA relative expression in thymus, spleen, kidney, liver and heart from 3- and 12 month-old rats are shown as mean \pm SEM. of three to five experiments performed in triplicate. Data for 12 month-old samples were normalized by those obtained for 3 month-old samples. Hprt gene was used as a housekeeping gene. Significant statistically changes in HIOMT mRNA expression were observed during aging. (*), $P<0.05$ and $(* * *), P<0.001$.

Figure 3. NAT activity levels in extrapineal tissues from different-aged rats. NAT activities were measured in thymus, spleen, liver, kidney and heart homogenate of 3and 12 month-old rats. Pineal glands were used as positive control. Data are expressed as mean \pm SEM of nine to ten experiments performed in duplicate. Significant differences for NAT activity were observed in liver and kidney from 12 month-old rats, (*), $P<0.05$ and $(* * *), P<0.001$. 
Figure 4. HIOMT activity in extrapineal tissues from different-aged rats. HIOMT activities were measured in thymus, spleen, liver, kidney and heart homogenate of 3and 12 month-old rats. Pineal glands were used as positive control of the assay. Data are expressed as mean \pm SEM of nine to ten experiments performed in duplicate. Significant differences for HIOMT activity were observed in spleen, liver and heart from 12 month-old rats. $(*), P<0.05$.

Figure 5. ELISA melatonin measurement in extrapineal tissue homogenates from 3- and 12 month-old rats. Rats were killed at midday and the tissues were removed, washed in physiology saline solution, and stored at $-20^{\circ} \mathrm{C}$ for its determination by ELISA. Values are expressed as $\mathrm{pg} / \mu \mathrm{g}$ of protein. Data are represented as mean $\pm \mathrm{SEM}$ of six to eight experiments. Significant differences in melatonin content were observed between measurements of 3- and 12 month-old rats. (*), $P<0.05$ and (***), $P<0.001$. 
Table 1. Sequences of AA-NAT, HIOMT and Hprt primers used in the Real Time PCR study.

Primer

AA-NAT forward AA-NAT reverse HIOMT forward HIOMT reverse HPRT forward HPRT reverse $5^{\prime}$ - sequence-3'

TGCTGTGGCGATACCTTCACCA

CAGCTCAGTGAAGGTGAGAGAT

TACGGGGACAGGAAGTTTTG

GTGCCACTTCTGGGTTCATT

CTCATGGACTGATTATGGACAGGAC

GCAGGTCAGCAAAGAACTTATATAGCC 
Figure 1

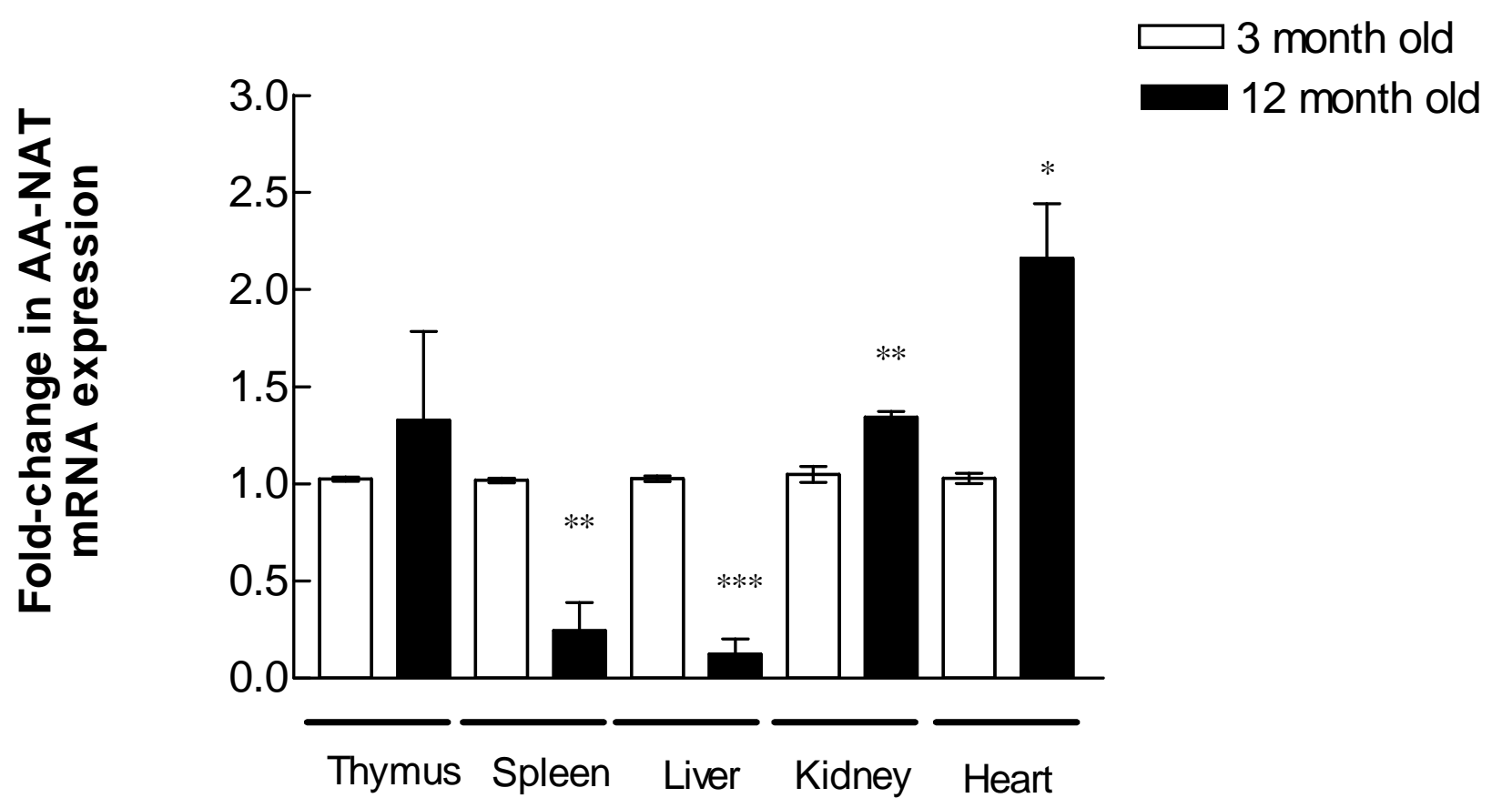


Figure 2

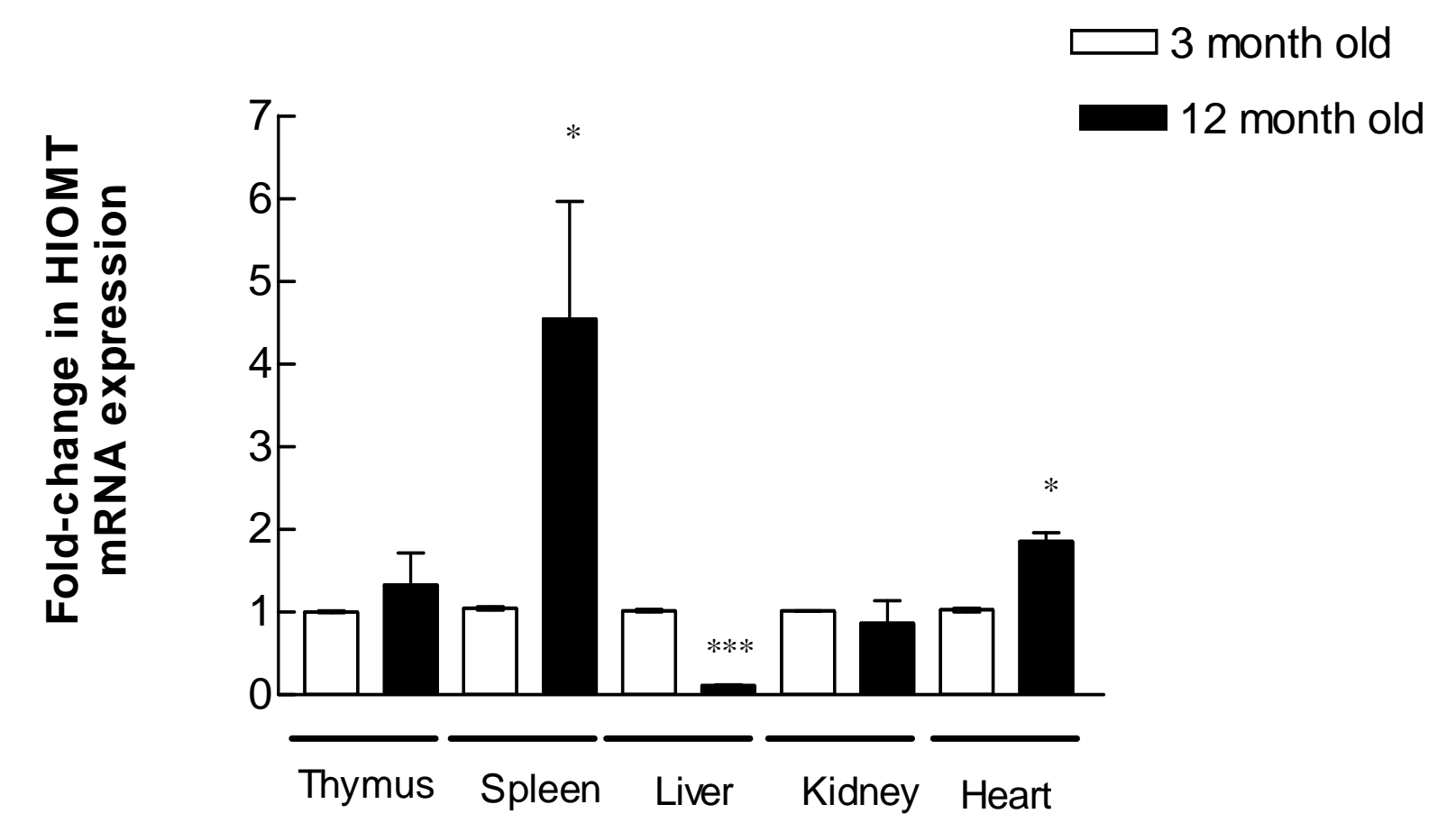


Figure 3

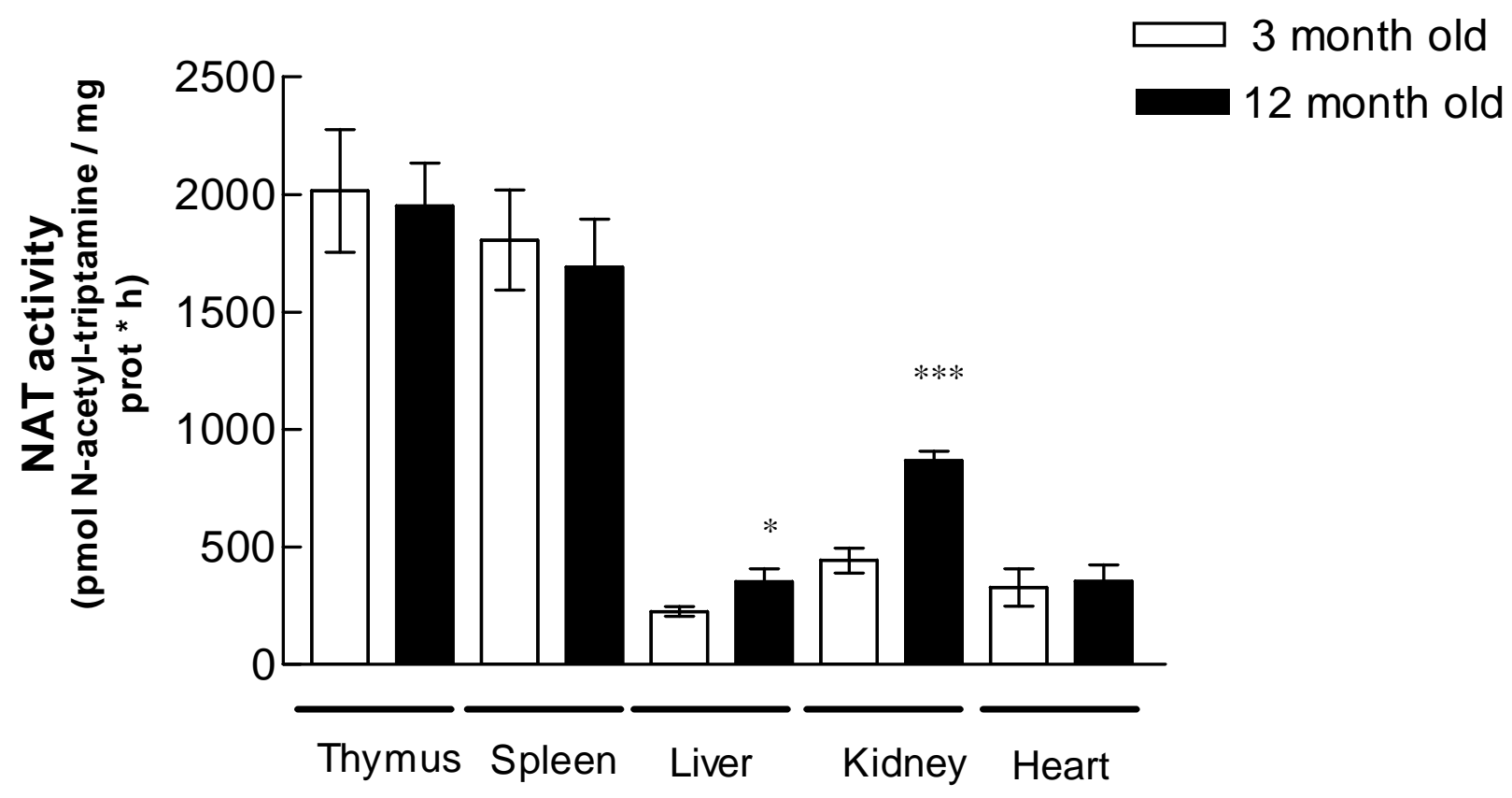


Figure 4

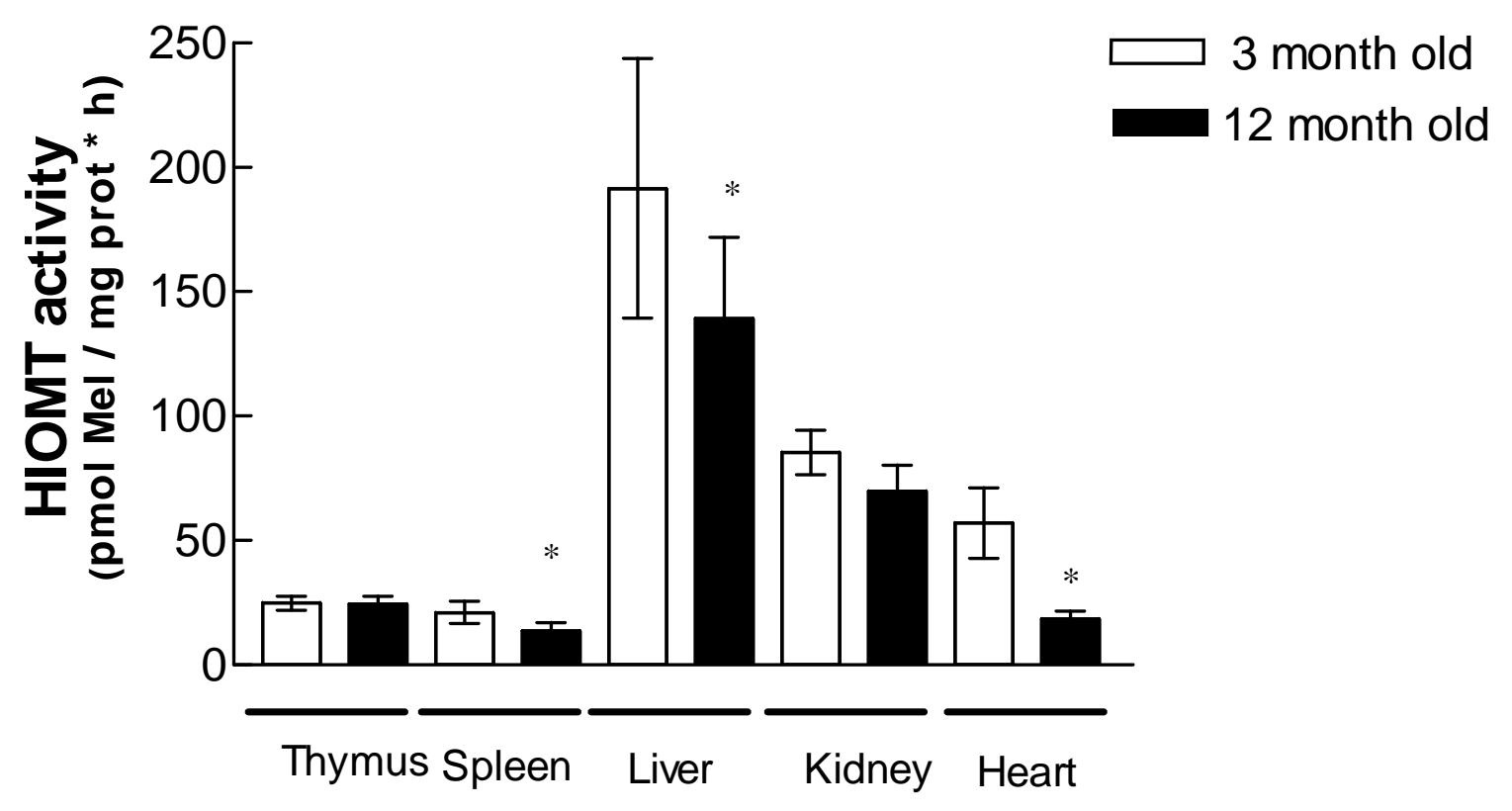


Figure 5

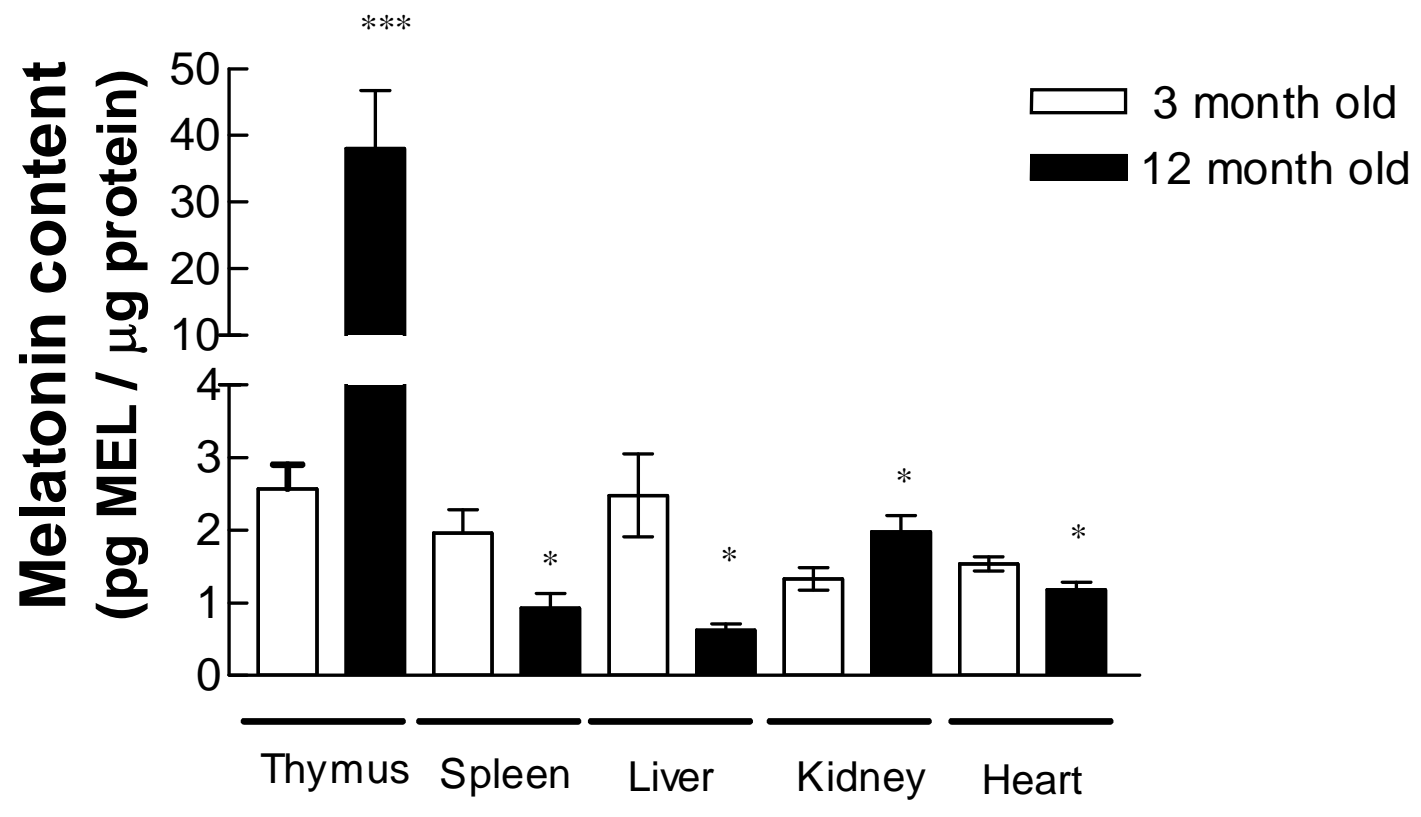

